\title{
PAWE BIELICKI
}

\section{Znaczenie relacji rosyjsko-czeczeńskich dla współczesnego bezpieczeństwa międzynarodowego}

\section{The significance of Russian-Chechen relations for contemporary international security}

\section{Abstract}

The main purpose of my work is to present the determinants and dependencies that characterize the Russian-Chechen relations for international political and economic security in the former Soviet Union and the Middle East, especially the Russian Federation.

At the beginning, I intend to trace the process of the Chechen war and consolidate the power of the current leader of the country, Ramzan Kadyrov with the help of the President Russia, Vladimir Putin. At the same time, I will present the geopolitical significance of Chechnya in the international security system. In the following, I would like to present the implications of Russian-Chechen relations for other countries of the former USSR area- Ukraine, where in all probability Chechen "volunteers" participated in the fighting in Donbas. Finally, an important element of this work will be signaling, that President Kadyrov, despite aware of the Kremlin's dependence on many matters, especially in economic terms, is starting to pursue an increasingly independent policy, as exemplified by the growing islamization of Chechnya, the participation of Chechen the Syrian conflict, Kadyrov active participation in the persecution of the Russian opposition, and finally the defense by the Chechen policy of the Muslim population of Rohingya in Myanmar against Moscow abstemious position. I would like to present the possible consequences 
of the above actions for the Russian Federation. It is not a secret that President Putin, despite the declared support for Kadyrov, is increasingly disapproving of some of his actions. In addition, it will be reasonable to present the reception of Kadyrov's activities in other post-Soviet areas.

In summary, I intend to answer the question whether major changes in the relations of both countries should be expected - and whether and how any changes will affect the architecture of international security.

Keywords: Safety, Chechnya, Kadyrov, Putin, Russia

\section{Значение российско-чеченских отношений для современной международной безопасности}

\section{Аннотация}

Главная цель моей работы - это представление обусловленности и зависимости, характеризующих российско-чеченские отношения для международной политической и экономической безопасности на территории бывшего Советского Союза, Ближнего Востока, а особенно Российской Федерации.

Сначала я намереваюсь проследить процесс чеченской войны и укрепление власти нынешнего главы республики Рамзана Кадырова с помощью президента России Владимира Путина. Одновременно я представлю геополитическое значение Чечни в международной системе безопасности. Далее я хотел бы представить последствия российско-чеченских отношений для других стран постсоветского пространства, например, для Украины, где вероятнее всего чеченские «добровольцы» участвовали в боях в Донбассе. И, наконец, важным элементом данной работы будет постановка тезиса, что президент Кадыров, несмотря на осознаваемую зависимость от Кремля во многих сферах, особенно в экономическом плане, начинает вести все более самостоятельную политику, примером чего является возрастающая исламизация Чечни, участие чеченцев в конфликте в Сирии, активное участие Кадырова в преследовании российской оппозиции и, наконец, защита чеченским политиком мусульманского населения рохинджа в Бирме вопреки сдержанной позиции Москвы. Я хотел бы представить возможные последствия вышеупомянутых действий для Российской Федерации. Не секрет, что президент Путин, невзирая на декларируемую поддержку для Кадырова, все с меньшим одобрением смотрит на некоторые его начинания. Кроме того, сообразным будет представить восприятие действий Кадырова в других странах постсоветского пространства. Подводя итоги, я попытаюсь ответить на вопрос, следует ли ожидать существенных изменений в российско-чеченских взаимоотношениях, а также или и какие возможные изменения повлияют на структуру международной безопасности?

Ключевые слова: безопасность, Чечня, Кадыров, Путин, Россия. 


\section{Wprowadzenie}

Charakter wydarzeń międzynarodowych na obszarze Bliskiego Wschodu, Ukrainy, Czeczeni lub chociażby Birmy rodzą dodatkowe i nieuchronne pytania o rolę Federacji Rosyjskiej oraz podległych jej rządów i administracji krajów trzecich - w tworzeniu, przebiegu i podsycaniu konfliktów w wyżej wymienionych miejscach. Przykład stanowi Czeczenia, rządzona przez Ramzana Kadyrowa, oskarżanego na Zachodzie o prześladowanie opozycji politycznej i dyktatorskie metody rządzenia, który świadom wsparcia udzielanego mu przez Putina, przez długi czas reprezentował całkowicie uległą politykę wobec swojego protektora, i unikał przy tym sporów z innymi przedstawicielami kremlowskiej administracji. W ostatnim czasie mamy jednak do czynienia z rosnącymi tarciami na linii Kadyrow - szefowie rosyjskich służb specjalnych, w obszarze wpływania na politykę Federacji i dostępu do Prezydenta Rosji. Nasilającej się rywalizacji sprzyjają nadchodzące wybory prezydenckie, określające już dziś ich wygranego i wielce prawdopodobne odejście Putina po 2024 r. ze względu na zakończenie wówczas jego drugiej kadencji prezydenckiej. Dlatego przedmiotem mojego zainteresowania jest charakterystyka relacji rosyjsko-czeczeńskich w odniesieniu do sytuacji w Syrii, na Ukrainie, w Birmie czy wreszcie w samej Rosji. Zamierzam poruszyć m.in. kwestię relacji Czeczenów z nastawionymi pro- i anty-rosyjsko przywódcami Europy Wschodniej, jak Aleksandr Łukaszenka oraz Petro Poroszenko. Ponadto celem tej dysertacji jest opisanie wydarzeń, które pozwalają postawić tezę o forsowaniu przez czeczeńskiego prezydenta większej jego samodzielności m.in. w nawiązywaniu wielopłaszczyznowych kontaktów z państwami bliskowschodnimi, bez naruszania dotychczas prowadzonej przez władze w Groznym twardej polityki wobec opozycji. Na wstępie kilka słów o okolicznościach dojścia Kadyrowa do władzy i utrwalenia jego pozycji politycznej.

\section{Dojście do władzy Kadyrowa i jego relacje z Rosją. Geopolityczne położenie Czeczenii}

Omawiając znaczenie Czeczenii w rosyjskiej polityce zagranicznej należy cofnąć się do okresu I i II wojny czeczeńskiej. Dla władz rosyjskich na czele z Borysem Jelcynem, narosłe w czasie pierwszej kampanii militarnej, 
problemy w aspekcie gospodarczym połączone ze spadkiem znaczenia międzynarodowego Rosji - oznaczały realną możliwość utraty kolejnych obszarów upadającego imperium. Zdając sobie z tego sprawę przywódcy polityczni i wojskowi na Kremlu powzięli decyzję o zaostrzeniu swoich działań. Podpisanie rozejmu w 1996 r., reelekcja schorowanego już i niezdolnego do podejmowania decyzji na miarę nadchodzących wyzwań prezydenta, wreszcie gwałtowny kryzys finansowy z 1998 r. i związany z nim spadek rubla o połowę swojej wartości, a także ustępliwa wobec Zachodu polityka zagraniczna Rosji - spotęgowały dążenia elit moskiewskich do zmiany prezydenta na młodszego, silniejszego, bardziej zdecydowanego i powiązanego ze służbami specjalnymi. Wybór padł na Władimira Putina, piastującego w tym czasie urząd szefa Federalnej Służby Bezpieczeństwa, urzędnika zdającego sobie sprawę, że w celu przybliżenia społeczeństwu jego kandydatury należy wykazać się stanowczością i siłą. Poszukiwał jedynie pretekstu do zaprezentowania tychże cech, co potwierdzają okoliczności wybuchu II wojny czeczeńskiej. Mimo utrudnionego dostępu do archiwów moskiewskich należy przypuszczać ze znaczną dozą prawdopodobieństwa, że to agenci FSB podłożyli bomby w budynkach mieszkalnych w Moskwie, zrzucając odpowiedzialność na czeczeńskich terrorystów (Felsztiński, Litwinienko, s. 9). Prowokacja ta osiągnęła zamierzony efekt, gdyż po rezygnacji Jelcyna Putin właśnie objął tymczasowo urząd prezydenta 31 grudnia 1999 r., parę miesięcy później zostając już pełnoprawnym, wybranym przez społeczeństwo prezydentem. Młodszy o 21 lat od poprzednika, podpułkownik FSB zdawał sobie sprawę, że wojna w Czeczenii jest milcząco akceptowana przez Zachód, dostrzegający w destabilizacji tego regionu możliwość dalszej destabilizacji obszaru postradzieckiego. Uwagę Zachodu skupiły wkrótce zamachy terrorystyczne z 11 września 2001 r. na wieże World Trade Center oraz Pentagon w Waszyngtonie. Jak trafnie konstatuje Agnieszka Legucka, zachodnie zainteresowanie konfliktem czeczeńskim wzrastało w miarę pogorszenia się relacji Rosji z Zachodem, zaś w przypadku dążeń Zachodu do poprawy kontaktów konflikt czeczeński ponownie stawał się problemem wewnętrznym Rosji. Powyższe potwierdzać ma zerwanie przez Rosję kontaktów wojskowych z NATO po interwencji zbrojnej Sojuszu w Jugosławii w marcu 1999 r. i gwałtowna fala krytyki na Zachodzie z powodu rozpoczęcia przez Rosję II wojny czeczeńskiej w sierpniu 1999 r. (Legucka, 2013, s. 239). 
Wydarzenia te Putin wykorzystał jako możliwość podkreślania, że tak jak Zachód walczy z terroryzmem na Bliskim Wschodzie, tak Rosja walczy z separatyzmem w Czeczenii. Moskwa stanęła w obliczu rozpoczętej wojny przed trudnym wyzwaniem, głównie z uwagi na różnorodność religijną tego obszaru. Czeczenia, położona na Kaukazie Południowym, jest przedmiotem zainteresowania najbardziej radykalnych grup muzułmańskich, skupionych głównie w środowiskach wahhabickich, powiązanych z Arabią Saudyjską. Sprawa czeczeńska stanowi pochodną niekonsekwentnej od czasów sowieckich polityki Kremla wobec islamu, kiedy to z jednej strony starano się nie dopuścić do zwiększonej aktywizacji tej religii w republikach azjatyckich, a z drugiej dostrzegano jej potencjał w starciu z oddziaływaniem chrześcijaństwa na terenie ZSRR, postrzeganego jako największy wróg komunistycznego ustroju. Wskutek podjętej przez Moskwę „czeczenizacji” konfliktu, religia ta miała przyczynić się do islamizacji kraju oraz zwiększenia w postradzieckich republikach uległości współpracy z nią. Jak zauważa Andrzej Wierzbicki, islam w Czeczenii, podległy nowym władzom w Groznym, stał się ideologią państwową, przyczyniającą się do legitymizacji władzy Kadyrowa (Szabaciuk, 2014, s. 55). Politykę obu tych ośrodków - Moskwy i Groznego - ułatwiają także datowane jeszcze na czas wojny i nie do końca jasne relacje pomiędzy fundamentalistami islamskimi. W jej czasie zarówno umiarkowany przywódca Asłan Maschadow, jak i przywódca czeczeńskich rebeliantów Szamir Basajew oraz radykalny przywódca Emiratu Północnego, Doku Umarow, reprezentowali odmienne poglądy na rozszerzenie islamu wśród pozostałych państw powstałych po rozpadzie ZSRR. Maschadow był zwolennikiem umiarkowanego islamu, kształtowanego wyłącznie w granicach Czeczenii. Natomiast Basajew, a szczególnie Umarow byli zwolennikami ekspansji islamu na pozostałe tereny Federacji. Sytuację skomplikowało zabójstwo 9 maja 2004 r. namaszczonego przez Moskwę jako Prezydenta Czeczenii Achmada Kadyrowa, dokonane w Groznym w czasie obchodów Dnia Zwycięstwa. Następcą został jego syn, Ramzan Kadyrow, z którym Putin zawarł nieformalny pakt, polegający na osobistym politycznym poddaniu się rosyjskiemu prezydentowi w zamian za finansowanie przez Moskwę odbudowy regionu. Ze strony młodego polityka wchodzą w grę również motywy osobiste, gdyż wielokrotnie podkreślał on wsparcie „moralne” Putina po śmierci ojca, traktując go jako swojego mentora. Również szef rosyjskiego 
państwa często podkreślał talenty polityczne Kadyrowa, mówiąc m.in.: „Szczerze nie oczekiwałem, że tak aktywnie weźmie się za gospodarowanie Czeczenią. Byłem w Groznym i widziałem, w jakim stanie znajdowało się to miasto po zakończeniu działań wojennych. No po prostu Stalingrad. Gdy chodziłem między ruinami, moją pierwszą myślą było: czy odbudowa tego miasta jest w ogóle możliwa? I jeśli możliwa - to kiedy? A on wziął się do roboty i odbudował miasto. No zuch, po prostu! Myślałem, że on tylko po górach z automatem umie się włóczyć - ale nie” (Zygar, 2017, s. 430).

Należy pamiętać, że Czeczenia, położona w samym centrum Kaukazu, jest jednym z najważniejszych dla Moskwy rejonów, niezbędnych w walce z państwami zachodnimi o wpływy w Azji, szczególnie na Bliskim Wschodzie. Kaukaz rozpościerający się na styku Azji i Europy, między Morzem Czarnym a Kaspijskim, stanowi możliwość realizowania przez Moskwę polityki globalnej i odzyskania dawnej pozycji politycznej, ukształtowanej za czasów ZSRR. Co ciekawe, obszar ten stanowi już od XVIII w. i momentu odkrycia złóż naftowych i surowców energetycznych przedmiot rywalizacji między Rosją, Turcją i Persją - także pod względem religijnym (Zając, 2016). Publicysta „Kursu Spraw Wschodnich”, Leon Bohdanowicz już w 1949 r. stwierdzał, że mniej więcej od połowy XIX w. można mówić o znacznej ekspansji ludności rosyjskiej na obszary zamieszkiwane przez wyznawców islamu, szczególnie Kaukazu, gdzie sprowadzili się Kozacy, w miejsce 600 tysięcy tutejszych Górali, którzy jako miejsce nowego osiedlenia wybrali Gruzję. Z kolei w Azji Środkowej przed 1917 r. aż 95 proc. mieszkańców reprezentowało wiarę muzułmańską, pomimo ciągłej dominacji Rosjan w większych miastach kraju oraz intensywnej kolonizacji w Kazachstanie (Bohdanowicz, 1949, s. 15). Wzrost znaczenia pozycji Sowietów na przedmiotowym obszarze był wynikiem występowania daleko posuniętych sprzeczności między Arabami a Kurdami, Ormianami, Druzami, Maronitami, Azerbejdżanami. Dla Ludwiga Bergera, publicysty „Dziennika Polskiego i Dziennika Żołnierza”, większe znaczenie miały różnice wyznaniowe, związane z podziałem na szyitów i sunnitów, a także na wyznawców judaizmu i chrześcijaństwa - czyli patriarchatu Greckiego Kościoła Ortodoksyjnego oraz Kościoła grekokatolickiego. Były one szczególnie obecne wśród przedstawicieli tzw. Kościołów wschodnich - koptyjskiego, nestoriańskiego, jakobickiego, syriackiego, chaldeeńskiego 
i gregoriańskiego, w mniejszym lub większym stopniu powiązanych z Moskwą (Berger, 1946, s. 2). Wychodząc od przedstawionego podziału, widzimy że Rosja miała historycznie dwa problemy, jeśli chodzi o geopolityczne znaczenie Czeczenii - mianowicie możliwość otwartej inwazji ze strony państw Bliskiego Wschodu oraz jej wpływ na położone w bezpośrednim sąsiedztwie Rosji republiki muzułmańskie.W pierwszym przypadku Czeczenia służy do dnia dzisiejszego jako rosyjska linia obrony, a jej utrata narażałaby Rosję na ataki terrorystyczne na większą skalę. W drugim scenariuszu, gdyby Czeczenia ogłosiła niepodległość, silnie muzułmańskie republiki - Dagestan na wschodzie i Inguszetia na zachodzie, mogłyby wpływać na jej działania, aby podążać za ich przykładem. Dagestan i Inguszetia są także strategiczne dla zakaukaskiej infrastruktury transportowej. Wybrzeże Morza Kaspijskiego w Dagestanie jest używane do przekraczania górskiego regionu i dostępu do bogatego w ropę naftową Baku. Dlatego destabilizacja w Czeczenii mogłaby otworzyć strategiczne drzwi dla przeciwników Rosji (Jacobson, 2012). Przechodząc stricte do zagadnień ekonomicznych, musimy stwierdzić, że głównym surowcem naturalnym w Czeczenii jest ropa naftowa. Podobnie jak Inguszetia i sąsiednie obszary Północnego Kaukazu, należy ona do najstarszych regionów Rosji wydobywających ropę i gaz. Główne zakłady produkcyjne ropy znajdują się w okolicach Groznego i osady Novogroznensky, a zasoby handlowe stanowią około $60 \mathrm{mln}$ ton i są w znacznym stopniu wyczerpane. Ogólnie znane rezerwy przekraczają $370 \mathrm{mln}$ ton, ale występują w wyjątkowo niesprzyjających warunkach geologicznych na głębokości 4,5-5 km. W chwili obecnej Czeczenia nie może z nich skorzystać, ponieważ nie posiada mocy wiertniczych ani wystarczającej liczby specjalistów. Dawne stowarzyszenie produkcyjne „Grozneft”, reaktywowane decyzją Kadyrowa w 2016 r. prowadziło wydobycie w obszarze 24 pól naftowych i gazowych, których zapasy uznano za przemysłowe. Największe rezerwy stwierdzono na Oktyabrskoye, Goriacheistochroszenskoje, Starogruźnenskoje, Pravobereżnoje, Bragunskoje, Severo-Bragunskoje i Eldarowskoje, które wyprodukowały 4/5 całkowitej ilości wydobycia ropy. Według wyników z 1998 r. Czeczenia wydobyła wówczas 846 tys. ton ropy, w tym kondensat gazowy (Geographic position, 2003). Eksploracja ropy sięga początków XX w. W latach 70. i 80 XX w. Czeczenia była głównym dostawcą produktów ropopochodnych dla ZSRR. Jednakże z chwilą rozpadu sowieckiego imperium nastąpił znaczący spadek produkcji 
surowca, co przyczyniło się pośrednio także do wojen rosyjsko-czeczeńskich. W celu zwiększenia ropy wydobycia władze czeczeńskie chcą przede wszystkim zbudować dużą rafinerię, która byłaby w stanie przerobić milion ton ropy rocznie i przynieść republice znaczne dochody. Oświadczyły one, że planują budowę zakładu produkującego baterie wspólnie z południowokoreańską firmą Kokam. Projekt ten zapewniłby ponad 2 tys. miejsc pracy dla mieszkańców republiki (Dżutsati, Putin Hands Oil, 2016). Lokalna gospodarka jest zdominowana przez ropę i gaz, a zwłaszcza przez małe i dobrze prosperujące pola naftowe położone na nizinach. Na obszarach wyżynnych natomiast można zauważyć duży potencjał ekonomiczny w zakresie energii wodnej (szczególnie wzdłuż rzek Terek i Argun) (Jacobson, 2012). Podkreślić także należy, że przez Kaukaz przebiegają najważniejsze linie transportu surowców energetycznych (m.in. ropociąg Baku - Noworosyjsk), ważne w kontekście gazociągu South Stream - oraz korytarz transportowy Północ - Południe, od Indii poprzez Iran do Europy (Szabaciuk, 2014, s.48-49). Obraz dopełnia fakt, że przez Czeczenię przepływa ropa naftowa z Morza Kaspijskiego nad Morze Czarne, a obsługujący ją rurociąg ma istotne znaczenie dla Moskwy, gdyż odkrywane są wciąż nowe złoża w Azerbejdżanie i Kazachstanie, będące przedmiotem zainteresowania zachodnich towarzystw naftowych (Pesnot, 2013, s. 259).

Należy podkreślić, że strona czeczeńska usiłuje maksymalnie wykorzystać swoje położenie geostrategiczne w celu wywalczenia jak największej ilości ustępstw ze strony Kremla. Służą temu dążenia Kadyrowa do zwiększenia kontroli nad wydobyciem ropy naftowej, wyłączające Rosnieft, rosyjskiego konsorcjum przeznaczającego zaledwie 0,23 proc całości swego budżetu na eksploatację złóż czeczeńskich (Dżutsati, Chechen Oil Takeover, 2016). Główna strategiczna firma naftowa w Czeczenii, Chechenneftekhimprom, - jest własnością rosyjskiej agencji nieruchomości Rosgosimushchestvo. Jej aktywa trwałe zostały wycenione w 2014 r. na 2 mld rubli. Obecnie zarządza nimi Rosnieft, aczkolwiek poszukiwaniem oraz wydobywaniem ropy zajmuje się spółka zależna Grozneftegaz, która dzierżawi część aktywów Chechenneftekhimpromu, w tym nieokreśloną liczbę odwiertów naftowych i gazowych (Fuller, 2016). Firma ta jest także właścicielem dwóch rafinerii ropy naftowej i jej magazynów. Grozneftegaz jest własnością Rosnieftu w 51 proc. i czeczeńskiego rządu w 49 proc. Niepokój na Kremlu wywołały słowa 
Kadyrowa, który stwierdził że jego rząd chce współpracować z południowokoreańską firmą Kokam w sprawie wykorzystania zasobów czeczeńskich i budowy zbudowania fabryki produkującej akumulatory litowo-jonowe. Jednakże czeczeński prezydent zmienił zdanie, twierdząc że Grozny będzie jednak naciskał na budowę rafinerii albo przez Grozneft albo przez innych inwestorów o rocznej wydajności $1 \mathrm{mln}$ ton (Fuller, 2017). Postawa Kadyrowa jest związana z pogorszeniem się relacji Putina z Igorem Sieczinem, szefem Rosnieftu, który ostatnio zaczyna dbać w większym stopniu o własne interesy, aniżeli kraju, co nie podoba się Putinowi. Rosyjski prezydent, zdając sobie sprawę z ambicji politycznych Sieczina, dymisjonując bliskiego mu szefa Rosyjskich Kolei Żelaznych, według wszelkiego prawdopodobieństwa próbuje ograniczyć jego pozycję, co w sposób nieunikniony prowadzi do jeszcze większego zbliżenia Putina z Kadyrowem, którego lojalność jest niepodważalna (Bestia Putina, 2016). Rozczarowany swoimi współpracownikami szef rosyjskiego państwa, świadomy że po dwudziestu latach od zdobycia władzy, umocnili oni znacząco swoje pozycje biznesowe i polityczne, jest coraz bardziej przekonany, że poprzez osobę Kadyrowa może utrzymywać w szachu kremlowskie klany, pogrążone w ciągłej walce o swoje strefy wpływów, szczególnie w dziedzinie szeroko pojętej energetyki. Chcąc zapobiec kryzysowi władze Rosnieftu złożyły czeczeńskiemu watażce dwie propozycje. Pierwsza z nich zakłada, że Rosnieft przejmie wszystkie aktywa przewidziane do budowy wspomnianej fabryki akumulatorów. Druga oferta przewiduje całkowite wycofanie się Rosnieftu z Czeczenii oraz wprowadzenie aktywów nieobjętych kontrolą przez Groznieftiegaz. Chociaż Kadyrow optuje za drugą opcją, to w grudniu 2016 r. federalny minister do spraw Kaukazu Północnego, Lew Kuzniecow, powiedział dziennikarzom, że nadal nie ma ustalonych szczegółów transakcji transferowych Czeczennieftiechimpromu. Również Sieczin zaostrzył swoje stanowisko, zawieszając na czas nieokreślony plan budowy rafinerii w Czeczenii o rocznej wydajności miliona ton, podpisany jeszcze w 2010 r. Zdając sobie sprawę z kunktatorskiego i mało wiarygodnego uzasadnienia Sieczina, sugerującego spadek popytu na ropę naftową, Kadyrow podpisał w listopadzie 2016 r. umowę z kanadyjską firmą Genoil dotyczącą „rozwoju projektów budowlanych i energii w Rosji i Czeczenii”. Projekt ten ma być skoncentrowany na przywróceniu produkcji ropy w Czeczenii, a ponadto przewiduje budowę rafinerii o rocznej zdolności produkcyjnej 
sięgającej 3-6 mln ton ropy. Co ciekawe, Genoil planuje wejść do Czeczenii razem z chińskimi podmiotami, które zapewnią finansowanie - szacowane na 15 miliardów dolarów. W rzeczywistości jednak plan Kadyrowa może nie być zrealizowany. Jak słusznie wskazuje Grzegorz Kuczyński, powodzenie transakcji zależy od pięciu czynników: zwiększenia wydobycia ropy w Czeczenii osobnego porozumienia między Moskwą a Pekinem dobrej woli Rosnieftu w zakresie praw do wydobycia ropy w Czeczenii przez samych Czeczeńców kosztów przedsięwzięcia oraz zapewnienia przez Genoil źródeł finansowania inwestycji (Kuczyński, 2016). Postawa Kadyrowa stanowi dla Kremla poważny problem. Wydaje się mało realne, że czeczeński polityk chce zrealizować wyłącznie zamierzenia wewnętrzne, oparte głównie na blokowaniu redukcji funduszy dla Czeczenii przez Rosjan czy zmianie umowy z Rosnieftem w zakresie dostaw ropy. Z czasem jego opinia może oznaczać nie tyle osłabienie pozycji Putina, co głównie destabilizowanie sytuacji politycznej w Rosji, gdzie władze muszą prowadzić niezwykle delikatną politykę wobec wszelkich mniejszości religijnych i etnicznych (Romańska, Górecki, 2017). Ponadto Kadyrow może z czasem prowadzić na własną rękę prowadzić politykę eliminowania ludzi niechętnych wobec siebie, ale powiązanych w mniejszy lub większy sposób z elitą rządzącą na Kremlu. Pomimo formalnego statusu rosyjskiego regionu Czeczenia znacznie różni się od innych podmiotów Federacji Rosyjskiej. Porzuciwszy walkę zbrojną, prezydent tego obszaru formalnie uzyskał względną niezależność w wyniku porozumienia z Rosjanami - w odróżnieniu od Dudajewa oraz Maschadowa. Jedynym warunkiem strony rosyjskiej, który miał spełnić, to utrzymanie spokoju w republice. W zamian za to Kreml miał przekazywać dotacje na rozwój kraju. Dlatego mimo wszystko to w interesie Kadyrowa jest pozostanie Czeczenii w obrębie Federacji Rosyjskiej, gdyż dzięki wsparciu Moskwy, może realizować on swoje cele polityczne i rozwijać siły zbrojne. Trafnie to scharakteryzował Oreszkin, mówiąc wprost: „Kadyrow corocznie wyłudza fundusze porównywalne [z potrzebnymi] do budowy elektrowni wodnej Bureisk. Każdego roku oddajemy jedną taką elektrownię wodną, zaś żaden obywatel rosyjski, który przyjedzie do Czeczenii, nie może liczyć na jego konstytucyjne prawa, a wszystko jest zależne od dobrej woli Kadyrowa”. Analityk sugeruje, że jeśli Kreml nie będzie w stanie spełnić jego żądań to może on ogłosić niepodległość i wprowadzić niezależny kurs dla Czeczenii 
we współpracy i przy pomocy państw islamskich. Oreszkin twierdzi wręcz, że region ten stał się niepodległym państwem, finansowanym przez Moskwę, która jest drenowana w zależności od potrzeb czeczeńskiego przywódcy (Jaszyn, 2016, s. 50). Tezę rosyjskiego politologa potwierdza także Wiktor Suworow, według którego Putin powtarza błędy carów, przeznaczając znaczne środki dla kraju, który z czasem obróci się przeciwko darczyńcy. Według pisarza Rosja zdominowana jest przez znakomicie zorganizowaną i bezwzględną czeczeńską mafię, natomiast sam Putin jest sługą Kadyrowa, który za rosyjskie pieniądze nie tylko dorobił się własnej fortuny, ale unowocześnił Czeczenię, a szczególnie Grozny (Suworow, 2014, s. 112-113). Nie bez podstaw niektórzy badacze stwierdzają, że rosyjskimi rękami Kadyrow, który coraz bardziej dostrzega własną rolę polityczną na Kaukazie i ogromne zasoby finansowe oraz energetyczne kraju, nie tylko pozbywa się swoich najgroźniejszych rywali politycznych, ale także w przypadku zaburzeń społecznych w Rosji, może albo podsycać konflikt, albo ogłosić niepodległość Czeczenii i nawet włączyć do swojego kraju niektóre zbuntowane przeciwko Moskwie, rosyjskie obszary. Ambicje Kadyrowa, by stać się liderem Kaukazu, są szczególnie widoczne we względnej niezależności Czeczenii. Stanowisko to potwierdza Irina Starodubrovskaya, regionalna ekspert ds. studiów w Instytucie Polityki Gospodarczej Gajdar, według której Kadyrow dąży do zapewnienia sobie przywódczej roli na Kaukazie (Jaszyn, 2016, s. 53). Z kolei według Andreya Yepifantseva, specjalisty od spraw politycznych na Kaukazie, taka polityka jest możliwa dzięki klanowej lojalności Czeczeńców, którzy nie zdradzają własnych ludzi i ukrywają ich często przed Moskwą, która chce osądzić część ludzi powiązanych z Kadyrowem za działania wojenne. Yepifantsev zauważa, że wszelkie rosyjskie próby zmaterializowania tego stanu rzeczy sprzyjają ponownym napięciom między Groznym a organami federalnymi władzy rosyjskiej, co może doprowadzić do chaosu i kolejnej wojny czeczeńskiej oraz wzmożonego szantażu Kadyrowa, który poprzez takie działania działa niezgodnie z rosyjskim prawem (Jaszyn, 2016, s. 53). Z drugiej jednak strony, ze względu na dążenie do realizowania swoich interesów za pomocą innych środków finansowych, za mało prawdopodobny należy uznać wariant oderwania się władz w Groznym od Rosji. 


\section{Aktywność międzynarodowa Kadyrowa na obszarze postradzieckim oraz na Bliskim Wschodzie}

W niniejszej analizie należy bez wątpienia przyjrzeć się aktywności czeczeńskiego lidera na terytoriach postradzieckich oraz bliskowschodnich, ze szczególnym uwzględnieniem Syrii. Aspekt ten jest o tyle istotny, o ile stanowi przedłużenie rosyjskiego pojmowania wielobiegunowych uwarunkowań tych obszarów niewypowiadanego oficjalnie i wprost $\mathrm{z}$ uwagi na obawę utraty międzynarodowego wizerunku oraz ujawnienie rzeczywistych poglądów i działań służących ich realizacji. Słowa czeczeńskiego prezydenta wypowiadane w kwestiach dotyczących tych obszarów są jednakże $\mathrm{w}$ wielu punktach zbieżne $\mathrm{z}$ rosyjskim ich rozumieniem. Zasadne jest więc twierdzenie, że w kontaktach z państwami Europy Wschodniej odgrywa on rolę tożsamą do funkcji Władimira Żyrinowskiego w rosyjskiej Dumie. Podstawowym jednak celem działania Kadyrowa poza granicami Czeczenii jest Ukraina. Nie ulega wątpliwości, że od początku tego konfliktu i aneksji Krymu, czeczeński prezydent jest jednym z najgłówniejszych orędowników bezwarunkowego wsparcia dla prorosyjskich separatystów w Donbasie. Reprezentował wręcz bardziej radykalne stanowisko w kwestii ukraińskiej niż Kreml, mając świadomość, że w odróżnieniu do Moskwy może mówić dużo bardziej bezpośrednio w obszarze działania „ukraińskich faszystów” skupionych wokół rządu w Kijowie. Chociaż stwierdza, że ochotnicy czeczeńscy pojechali na front $z$,potrzeby serca”, to jasnym jest, że realizuje podstawowe dyrektywy Putina, podkreślając usilnie, że władze w Kijowie wywołały wojnę przeciwko własnemu narodowi. „Ochotnicy” ci skupieni są głównie w batalionie Wostok wespół z Rosjanami pochodzenia ukraińskiego. Wkład Kadyrowa w możliwe rozwiązanie sporu podkreśla rosyjski politolog, Nikołaj Siłajew, mówiąc że: „[a]ktywne uczestnictwo w kwestach ukraińskich ukazuje go jako dużego gracza politycznego w ramach przestrzeni postsowieckiej, i już powoduje następstwa poza Rosją. Opłaciły się jego starania w pracy z zagraniczną diasporą czeczeńską). W opinii badacza Kadyrow dąży do ostatecznego pozbawienia wszelkich wpływów lidera czeczeńskiego rządu na emigracji, zwłaszcza Achmeda Zakajewa oraz jednoczesnego sprowadzenia zagranicznych inwestorów do Czeczenii w celu dalszej konsolidacji rozwoju ekonomicznego państwa i chociażby częściowego uniezależnienia się od 
Moskwy w tej sferze (Soska, 2014). Wydaje się uzasadnione stwierdzenie, że o znaczeniu rzeczywistych wpływów Kadyrowa na Ukrainie świadczy uwolnienie dwóch rosyjskich dziennikarzy, zatrzymanych wcześniej przez ukraińską armię. Bezpośrednio po uwolnieniu zostali przewiezieni do Groznego.W zakresie realnych celów czeczeńskiej polityki analitycy podkreślają, że prezydent Kadyrow dąży także do poprawy wizerunku swego narodu wśród Rosjan, wielokrotnie postrzeganego jako ludzie gorszej kategorii. Stopniowo za sprawą brutalnego, ale energicznego lidera, lojalnego wobec Moskwy, Czeczeni zaczynają zdobywać coraz większe poparcie w rosyjskim społeczeństwie (Soska, 2014). Poprawie tego wizerunku sprzyjają także wypowiedzi Kadyrowa, odwołujące się do odbudowy przez Moskwę imperium zewnętrznego na obszarze postradzieckim. Przykładowo, że Ukraina stanie się ostatecznie częścią przyszłego stanu „wielkiej Rosji”. Komentarz taki pojawił się krótko po tym, jak ukraiński urzędnik Georgie Tuka zapowiedział dziennikarzom, że główne zadanie obecnych władz w Kijowie polega na rozbiciu Rosji na części. Kadyrow oświadczenie Tuki nazwał „najbardziej tajnym marzeniem prezydenta Poroszenki i innych antyrosyjskich osób zajmujących wysokie stanowiska na Ukrainie" i zaznaczył, że takich sformułowań nie można pozostawić bez odpowiedzi. Napisał, że „ani Tuka, ani Poroszenko nigdy nie zobaczą Rosji słabej i upadającej”. I dalej: „potomkowie Tuki i Poroszenki będą mądrzejsi od swoich przodków i będą szukać miejsca w «wielkiej Rosji» (Kadyrov predicts, 2017). Należy także pamiętać, w kontekście kryzysu ukraińskiego, że Kadyrow z dużą dozą prawdopodobieństwa jest wykorzystywany przez Kreml do fizycznej likwidacji niewygodnych dla Moskwy i separatystów polityków ukraińskich, czego przykładem może być zabójstwo deputowanego do Rady Najwyższej Ukrainy Igora Mosijczuka (Górzyński, 2016). Analizie poddano także morderstwo dokonane w Kijowie na Adamie Osmajewie oraz Annie Okujewej, przeciwnikach czeczeńskiego reżimu. Niniejsze uruchamiają dwie możliwe konsekwencje. Napaść na członków antymoskiewskiej społeczności czeczeńskiej wskazuje, że Kadyrow, który wcześniej zarządził i finansował podobne ataki, realizuje swoją długoterminową strategię eksterminacji swoich przeciwników bez względu na ich miejsce przebywania. Jego zdolność do mobilizowania, dowodzenia za granicą i do wysyłania wybranych przez siebie zabójców bezpośrednio z Czeczenii lub Rosji, pozostaje niezmieniona. Cele tych ataków są wybierane 
niekoniecznie w kolejności ich znaczenia - Osmajew i Okujewa są raczej osobami małoistotnymi, jeśli chodzi o bezpieczeństwo reżimu czeczeńskiego (Aliyev, 2017), ale poprzez takie wydarzenia Kadyrow szerzy strach wśród zwykłych Ukraińców, nieposłusznych Kremlowi, żeby zaakceptowali istniejący stan rzeczy i podjęli próbę obalenia władz w Kijowie.

Innym polem działalności międzynarodowej czeczeńskiego lidera jest Białoruś. Mimo deklarowanej od wielu lat przyjaźni z prezydentem Łukaszenką, relacje obu państw w rzeczywistości nie są zbytnio zintensyfikowane. Dopiero kilka miesięcy temu Prezydent Czeczenii przyjechał do Mińska, gdzie zapewnił, że „marzył o osobistym spotkaniu” z białoruskim przywódcą, który na Kaukazie jest szanowany za to, że jak mówi: „buduje Pan państwo, broni interesów swojego narodu na najwyższym poziomie. Wasz kraj nie jest nam obojętny. I nasze kraje od dawna są związane przyjacielskimi, bratnimi stosunkami”. Łukaszenka z kolei powiedział, że Białoruś jest dobrze poinformowana o rozwoju Czeczenii i wyraża radość z powodu odbudowy kraju ze zniszczeń wojennych. Szef białoruskiego państwa stwierdził wprost, że „dla nas Republika Czeczeńska to region pełen perspektyw i cieszący się autorytetem” oraz że „najważniejsza jest «braterska» budowa swoich relacji z przedstawicielami wielonarodowej Rosji, z którymi widzimy tendencje do pogłębienia wzajemnych kontaktów” (Łukaszenka i Kadyrow, 2017). $Z$ wypowiedzi Łukaszenki wynika po pierwsze, chęć wzmocnienia uznania w oczach Moskwy, ponieważ wyraźnie podkreśla, że Czeczenia należy do podmiotów wielonarodowej Rosji. Innymi słowy białoruski prezydent nie uważa Czeczenii za podmiot niepodległy, lecz za kraj ściśle powiązany z „narodami Rosji”. Po drugie, należy zwrócić uwagę na czas wizyty Kadyrowa w Mińsku. Nie ulega wątpliwości, że w obliczu pogarszania się sytuacji wewnętrznej na Białorusi i kolejnych problemów gospodarczych tego państwa, mógł on być swoistym wysłannikiem Kremla, chcącym przyjrzeć się sytuacji na miejscu i aby dokładniej zlustrować postawę białoruskiego przywódcy. Sam Łukaszenka również może dążyć do pozyskania w osobie czeczeńskiego prezydenta, mediatora w przypadku wystąpienia możliwych napięć z Putinem lub jego potencjalnym następcą. Pamiętajmy o tym, że mimo pewnych różnic, głównie w wymiarze osobowościowym, liderzy Rosji i Białorusi, od czasu objęcia przez Putina urzędu prezydenta, byli zdolni do porozumienia się w najważniejszych dla siebie sprawach i darzą się zaufaniem, wiedząc że 
Białoruś mimo wyrażanych publicznie dążeń do poprawy relacji z Zachodem nigdy nie odwróci się od Rosji, chociażby ze względu na rosnące uzależnienie ekonomiczne od Moskwy oraz jednak podobne poglądy na kwestie ustrojowe. Także Kadyrow może stać się dla Białorusi użyteczny przede wszystkim z jednego powodu. 63-letni Łukaszenka obawia się rezultatów walki o schedę po Putinie, która z dużą dozą prawdopodobieństwa przybierze na sile już od początku kolejnej kadencji prezydenckiej obecnego rosyjskiego lidera. Białoruski prezydent świadomy jest, że po Putinie może na kremlowskim tronie zasiąść polityk, który będzie mniej skłonny do wspierania ekonomicznego Białorusi i może ze względów wiekowych, zechcieć dokonać zmiany w Mińsku, podburzając tutejsze ściśle powiązane z FSB służby specjalne, do wywołania określonego buntu przeciwko obecnej władzy i niedopuszczenia do objęcia władzy na Białorusi przez syna przywódcy, Wiktara. Chcąc zapewnić synowi sukcesję Łukaszenka z całą pewnością dąży do nawiązania kontaktów z Kadyrowem, który mimo potęgujących napięć z rosyjskimi stronnictwami siłowymi poprzez lojalność wobec Putina zgromadził pewne wpływy polityczne w administracji kremlowskiej, które z czasem mogą stać się dla białoruskiego satrapy niezwykle pożyteczne. Jednocześnie jego oczekiwania względem Moskwy mogą okazać się wysoce problematyczne. Wiąże się to z postrzeganiem Białorusi przez Rosję. Wypada się zgodzić z jednym analitykiem Andriejem Porotnikowem, który powiedział wprost, że Kreml wcale nie darzy Białorusi przyjaźnią, a realizuje tam jedynie swoje interesy. W przypadku konieczności jej porzucenia Moskwa wykona taki krok bez mrugnięcia okiem. Białoruś nie może w chwili obecnej liczyć na żadne inne państwo (Białoruś została sama, 2017).

Kolejnym polem działania Kadyrowa jest Syria. Prowadząc bezwzględną grę dyplomatyczną na tym obszarze Putin zamierza przywrócić Rosji, według niego, należny jej „właściwy” status geostrategiczny na świecie. Jednym z ważniejszych rozstrzygnięć służących temu celowi jest kwestia czeczeńska. Wzrost siły Państwa Islamskiego oznaczał wzmożoną aktywizację radykalnych grup islamskich na terenie Federacji Rosyjskiej i Czeczenii (Bielicki, 2016, s. 209). Według Edwarda P. Djerejiana, podejmując interwencję militarną w Syrii. Prezydent Rosji obawiał się wzrostu znaczenia w swoim kraju islamskiego fundamentalizmu w postaci radykalnych ruchów w Dagestanie, potęgowanych wyjazdem około 2 tys. Rosjan z różnych grup etnicznych, 
do walki w Syrii po stronie ISIS (Risky Russian moment, 2015). Zasadniczo podobnie rozumiał niniejszą kwestię inny analityk Rusłan Pukhov. Zaznaczał on ponadto, że efektem rosyjskich nalotów miało być usunięcie możliwości zachodniej interwencji w Syrii, zwiększenie presji na ISIS w celu ograniczenia jego ekspansji na Kaukazie, zagrażającej bezpośrednio bezpieczeństwu Rosji (Pukhov, 2015).Z kolei Yuli Nisnevich, profesor w Wyższej Szkole Ekonomii w Moskwie, twierdzi że Kadyrow dał zielone światło radykalnym islamistom dla opuszczenia Czeczenii. Zdaniem analityka wysłanie ich na Bliski Wschód jest jego autonomiczną decyzją, której celem jest pozbycie się z Czeczenii wszelkich osób, zdolnych do przejęcia w przyszłości po nim sterów rządów w kraju. Jednocześnie Nisnevich wyraża pogląd, że dla czeczeńskiego prezydenta nie ma jednak znaczenia to, co się stanie w przypadku ich powrotu do Czeczenii oraz do Rosji (Jaszyn, 2016, s. 56). Inny politolog, Mayrbek Vachagaev, także twierdzi, że około 1,5 tys. osób opuściło terytorium Czeczenii i wyjechało do Syrii, przy czym nie ma możliwości dokładnego oszacowania tych danych. Jedynie 10 proc. z nich jest narodowości czeczeńskiej, natomiast większość, stanowiąca około 50-60 proc., kraj ten jedynie zamieszkiwała, a pochodzi z Bliskiego Wschodu, w szczególności z Turcji i Syrii (Ноде, 2014). W opinii Czesława Kosiora z Ośrodka Analiz Strategicznych, jeszcze pod koniec $2012 \mathrm{r}$. do Syrii przez Turcję byli masowo przerzucani ochotnicy z Kaukazu Północnego (Państwo Islamskie a Rosja, 2015). Ekspert do spraw służb specjalnych Andriej Sołdatow przypomina natomiast, że w przeszłości rosyjski wywiad wykorzystywał też diasporę czeczeńską w Syrii w celu nawiązania kontaktów z założycielem Al-Kaidy w Iraku, Abu Musabem Al-Zarqawim. Wątpliwości nasuwa działalność w ISIS dwóch osób - zabitego w marcu 2016 r. w amerykańskim ataku - Abu Umar al-Sziszaniego, czyli Tachana Batiraszwilego, oraz Muslima Abu Walid al-Sziszani - Murada Margoszwilego. Pierwszy z nich walczył w gruzińskiej armii przeciwko Rosji w 2008 r., zaś po wojnie zaangażował się w działalność partyzancką na Kaukazie Północnym. Wedle nieoficjalnych informacji przybył do Syrii w 2012 r. Gruziński dziennikarz Nino Burchuladze uważa, że Batiraszwili rozpoczął „karierę" w Syrii w grupie Dżabat Al-Nusra blisko związanej z Al-Kaidą. Po konflikcie z Rusłanem Machalikaszwilim, jednym z najważniejszych w tej organizacji Czeczenów, dołączył do ISIS (Menadbe, 2015) i do śmierci był ministrem wojny w „rządzie” tego „państwa”. Natomiast Margoszwili jest 
weteranem wojny czeczeńskiej, walczącym wcześniej w oddziałach Samira Basajewa i Rusłana Giełajewa, jednego z czeczeńskich watażków związanego z GRU. Pomimo oskarżenia przez Rosjan o terroryzm, dostał wyrok zaledwie dwóch lat więzienia, a następnie został uniewinniony i prawdopodobnie przy udziale FSB w 2012 r. trafił do Syrii. Nie jest też tajemnicą, że w ISIS czynną rolę odgrywają przedstawiciele dawnej partii Baas zajmujący wysokie stanowiska w rządzie Saddama Husajna w Iraku, w mniejszy lub większy sposób wykorzystywani przez Kreml do zrealizowania jego celów w Europie. Wyraźnie podkreśla to Kosior, wykazujący w obszernej analizie m.in., że walczący po stronie ISIS, Ibrahim Awwad Ibrahim Al-Badri, znany jako Abu Bakr Al-Bagdadi, ma powiązania rodzinne z członkami partii Al-Bas, m.in. są to dwaj wujowie należący do służb specjalnych irackiego dyktatora. Zdaniem Kosiora główną rolę w powstaniu Państwa Islamskiego odegrał Samir Abd Muhammad al-Khlifawi, za czasów Husajna pułkownik wywiadu wojskowego sił powietrznych Iraku (Państwo Islamskie a Rosja, 2015).

\section{Kadyrow a rosyjskie służby specjalne}

Istotnym wątkiem niniejszych rozważań jest analiza kontaktów prezydenta Kadyrowa z rosyjskimi służbami specjalnymi. Nie budzi wątpliwości, że jego rosnące ambicje są przyjmowane $z$ dezaprobatą przez kierownictwa FSB i GRU, obserwujące z niepokojem także pewną zależność od niego osoby Prezydenta Federacji Rosyjskiej. Skrywany przez długi czas konflikt wybuchł w 2015 r., kiedy to w kwietniu tegoż roku funkcjonariusze MSW Kraju Stawropolskiego przeprowadzili na terytorium Czeczenii operację, podczas której zginął poszukiwany listem gończym obywatel tego kraju. Akcja rosyjskich służb specjalnych spotkała się z ostrym sprzeciwem Kadyrowa, który stwierdził, że o przebiegu operacji nie został poinformowany. Co więcej, czeczeński przywódca podkreślił, że podległe mu służby specjalne będą od tej pory otwierać ogień do każdego, kto nie uzgodni z nim przebiegu określonych akcji. Wyraził jednocześnie bezwarunkową gotowość do akceptowania rozkazów Putina (Falkowski, Żochowski, 2015). Powyższe wydarzenie jest jednym z przejawów rosnących napięć pomiędzy strukturami siłowymi Rosji a władzami Czeczenii. Należy wymienić ich dwie przyczyny - walka o władzę na Kremlu oraz zabójstwo Borysa Niemcowa, 
o które rosyjskie służby oskarżają Kadyrowa, a bezpośrednio dowódcę batalionu „Północ” - Rusłana Gieriemiejewa oraz jego podwładnego - Zaura Dadajewa. W grę może także wchodzić konkurencja z Czeczenami odnośnie interesów świata przestępczego oraz rywalizacja o zyski z nielegalnych operacji służb specjalnych. Powyższe jest $\mathrm{z}$ niepokojem obserwowane przez władze w Moskwie, które z jednej strony nie mogą usunąć Kadyrowa ze względu na zaprowadzoną przez niego stabilizację wewnątrz Czeczenii, ale z drugiej nie mogą spokojnie przyglądać się rywalizacji z organami władzy federalnej (Falkowski, Żochowski, 2015). Dla struktur siłowych niebezpieczna jest aktywność w sferze biznesu Prezydenta Republiki Czeczeńskiej na obszarze Federacji Rosyjskiej, szczególnie w zakresie przestępczości zorganizowanej. Rosyjska policja nie jest w stanie kontrolować działalności czeczeńskiej mafii, która np. ściąga haracze od przedsiębiorców rosyjskich m.in. na Krymie. Niejasną kwestią jest także funkcjonowanie Fundacji im. Achmada Kadyrowa i źródeł jej finansowania. Chociaż teoretycznie prowadzi ona w Czeczenii, Rosji i poza jej granicami - działalność „dobroczynną”, to w rzeczywistości może stanowić przykrywkę dla nielegalnych interesów Kadyrowa i jego zauszników. Niepokój dodatkowo wzbudza utrzymywanie przez rząd Czeczenii kontaktów z rodzimą diasporą za granicą, m.in. w Europie i na Bliskim Wschodzie (Falkowski, 2015).

Najnowszym przejawem opisywanych napięć z rosyjskimi siłowikami są wydarzenia w Birmie, gdzie we wrześniu 2017 r. doszło do prześladowań muzułmańskiej ludności Rohingya, mniejszości narodowej, niechętnej przymusowej ich buddyzacji. Kadyrow już 2 września otwarcie stwierdził, że jeśli Rosja wesprze władze birmańskie, to on będzie „przeciwko Rosji”. Jako groźbę skierowaną wobec Moskwy można potraktować demonstracje muzułmańskich uchodźców pod ambasadą Birmy oraz zorganizowanie przez Kadyrowa wiecu w Groznym, podczas którego wezwano Putina do osobistej ingerencji w konflikt birmański i zakończenie prześladowań muzułmanów. Wydaje się uzasadnione stwierdzenie, że ta bezpośrednia groźba spełniła swoje zadanie, gdyż w czasie szczytu BRICS ${ }^{1}$ Putin wezwał publicznie rząd w Birmie do respektowania praw człowieka i zakończenia sporu na drodze

\footnotetext{
${ }^{1}$ BRICS - nazwa organizacji zrzeszająca państwa „rozwijające się” - Brazylię, Rosję, Indie, Chiny i Republikę Południową Afryki.
} 
pokojowej. Rosyjski prezydent, odnosząc się do krytyki ze strony Kadyrowa, stwierdził wprost, że każdy obywatel ma prawo wyrażać krytyczną opinię na temat polityki zagranicznej państwa. Co ciekawe, szef czeczeńskiego państwa podziękował mu potem za zajęcie takiego stanowiska, w dalszym ciągu deklarując lojalność wobec Federacji Rosyjskiej (Romańska, Górecki, 2017). Jego postawa wobec konfliktu w Birmie wiąże się z kilkoma zagadnieniami. Po pierwsze, chce pokazać wewnętrznej opinii publicznej, że jego ambicje w polityce nie ograniczają się do bliskiej zagranicy. Nie jest tajemnicą, że nawiązuje on coraz szersze kontakty na Bliskim Wschodzie m.in. w Arabii Saudyjskiej, Jordanii czy wśród przywódców palestyńskich (Publicly Out Of Step, 2017). Należy stwierdzić, że był jednym z autorów porozumienia Gazpromu z władzami Bahrajnu odnośnie poszukiwań ropy i gazu w Czeczenii. Po spotkaniu z królem Bahrajnu - Hamadem bin Isa Al Kalifem - Kadyrow powiedział, że „osiągnięto porozumienie z Gazpromem w sprawie udziału w poszukiwaniach złóż ropy i gazu”, a władca Bahrajnu wyraził zainteresowanie ścisłą współpracą z Czeczenią w sferze gospodarczej, społecznej, kulturalnej i sportowej, wydając jednocześnie odpowiednie instrukcje swoim wicepremierom i ministrom (Gazprom agrees, 2017).

Czeczeński prezydent, poprzez demonstracje przeciwne rozpowszechnianiu karykatur Mahometa po zamachu na redakcję Charlie Hebdo we Francji w 2015 r., pokazuje także wewnętrznej opinii publicznej, że wyłącznie on broni islamu oraz pomaga zwiększyć wpływy Moskwy w państwach bliskowschodnich, częstokroć przeciwnych polityce Stanów Zjednoczonych. Zresztą Kadyrow, broniąc zamachowców, powiedział otwarcie: „Gdy trzeba, jesteśmy gotowi umrzeć, aby powstrzymać każdego, kto nieodpowiedzialnie myśli, aby zbezcześcić imię proroka. Wszyscy powinni to zrozumieć, w tym ci, którzy bez skrupułów ignorują opinię setek milionów muzułmanów”. Również Zakri Mamilov, współpracownik Kadyrowa, kontynuując jego myśl, oświadczył że strzelanie w biurze Charlie Hebdo w Paryżu „nie było atakiem terrorystycznym, ale karą Boga" (Jaszyn, 2016, s. 58). Nieprzypadkowa w tym kontekście jest także aktywność Kadyrowa dotycząca sprowadzania do Czeczenii dzieci rodziców, którzy walczyli po stronie Państwa Islamskiego na ogarniętych wojną terenach Syrii i Iraku. Poprzez reputację obrońcy pokoju, czeczeński przywódca pokazuje, że zarówno Rosja, jak i Czeczenia prowadzą w Syrii pokojową politykę, nakierunkowaną na zakończenie 
działań wojennych i doprowadzenie do trwałego rozejmu przy utrzymaniu u władzy prezydenta Asada. Jednocześnie próbuje poprzez wspomniany konflikt birmański nawiązać relacje z neutralnymi państwami Azji Południowo-Wschodniej, jak np. Indie i przy okazji pozyskać w nich kontrakty ekonomiczne. Za przykład służyć może służyć nawiązanie przez Czeczeńców kontaktów z Izraelem, w czasie których podpisano umowy dotyczące współpracy między oboma podmiotami (Suckhov, 2016). Paradoksalnie, ze względu na swoje strategiczne położenie Czeczenia może mieć, większe niż Kreml, możliwości nawiązania multilateralnych kontaktów z państwami azjatyckimi, gdyż Moskwa z uwagi na swoje dążenia mocarstwowe nie jest tam zbyt dobrze widziana, a ich przywódcy w stopniu niewystarczającym dostrzegają jej związki z Kadyrowem i z tego też względu są bardziej otwarci na zawieranie określonych kontraktów z Czeczenią jako regionem rozwojowym. Według Roberta Chedy protesty Czeczeńców są koordynowane bezpośrednio z Kremlem, gdyż Moskwie zależy na powrocie na Bliski Wschód, a muzułmanie powinni zdać sobie sprawę, że ich interesy będą reprezentowane za jej wstawiennictwem. Cheda wskazuje także, że do Czeczenii płynie dużo funduszy z Zatoki Perskiej i Kadyrow jest niejako zmuszony spłacać swój dług, także czynnie wspierając np. rzeczoną wcześniej muzułmańską mniejszość w Birmie. Analityk kategorycznie wykluczył jakikolwiek jawny sprzeciw Kadyrowa wobec Moskwy (Górzyński, 2017). Na użytek wewnętrzny i zewnętrzny chce on podkreślić, że nie jest satelitą Kremla i w niektórych sytuacjach potrafi wyrazić własny punkt widzenia, jednocześnie pokazując że jest muzułmańskim liderem, broniącym społeczności muzułmańskich poza granicami swojego kraju. Dlatego też skrytykował rosyjskie media dystansujące się od jawnego poparcia muzułmańskiej mniejszości w Birmie. Żądając od Rosjan podjęcia natychmiastowych działań w ich obronie, pod pretekstem ochrony kobiet, dzieci oraz osób starszych, $\mathrm{z}$ dużą dozą prawdopodobieństwa chce naruszyć solidarność międzypaństwową w Rosji (Publicly Out Of Step, 2017). Należy pamiętać, że islamski terroryzm zawsze był wykorzystywany przez rosyjskie władze jako pretekst do zaostrzenia represji politycznych względem własnego społeczeństwa. Można przypuszczać, że Kadyrow będzie dążył do zmiany wizerunku muzułmanów w Federacji Rosyjskiej dla zwiększenia ich oddziaływania na życie polityczne Kremla. 


\section{Zakończenie}

Jak relacje rosyjsko-czeczeńskie wpłyną na bezpieczeństwo międzynarodowe? W mojej opinii nie należy się w najbliższym czasie spodziewać zmiany ich natury i intensyfikacji. Nadchodzące wybory w Rosji i kolejna reelekcja Putina na stanowisko prezydenta, może przyczynić się do utrwalenia strategicznej roli Czeczenii w polityce zagranicznej Federacji Rosyjskiej. Z drugiej jednak strony, w dobie konieczności nieuniknionego poszukiwania jego następcy, Kadyrow z podległymi mu służbami może odegrać poważniejszą niż dotychczas rolę w nowym rozdaniu. Bardzo mało prawdopodobny jest bezpośredni wpływ czeczeńskiego prezydenta na wybór rosyjskiego odpowiednika, lecz nie można wykluczyć scenariusza, że osoba Kadyrowa może być użyta przez szefa rosyjskiego państwa jako straszak dla niepokornych urzędników, przeciwnych następcy mającemu być wyznaczonym przez Prezydenta Federacji.

W kontekście relacji na obszarze postradzieckim z dużą dozą prawdopodobieństwa należy stwierdzić, że w przypadku problemów Moskwy z opornymi państwami, takimi jak Ukraina - Kadyrow będzie dążył do zaogniania sporu, szukając pretekstów do jawnej interwencji Moskwy w sprawy wewnętrzne tego kraju. Zasadne jest przypuszczenie, że w dobie ostatniej kadencji prezydenta Putina będzie także chciał pogorszyć wizerunek Kremla na arenie wewnętrznej i zewnętrznej, przedstawiając jednocześnie siebie jako „bojownika o pokój”, zainteresowanego wyłącznie współpracą ze wszystkimi narodami kaukaskimi oraz postradzieckimi.

Relacje rosyjsko-czeczeńskie będą zależały także od sytuacji ekonomicznej Federacji Rosyjskiej. Tutaj wchodzą w grę przede wszystkim dwa czynniki: cena ropy naftowej oraz subsydia, przekazywane przez Moskwę corocznie Kadyrowowi. Kreml zdaje sobie sprawę, że wstrzymanie takich dotacji spotęguje możliwość buntu czeczeńskiego prezydenta, może oznaczać chaos w kraju i jego przyzwolenie na ataki terrorystyczne na powiązane z Moskwą instytucje, co dla poszukującego następcy Putina będzie stanowiło istotne utrudnienie. Dlatego należy ze zdwojonym zainteresowaniem obserwować wydarzenia na przedmiotowym obszarze. 


\section{MGR PAWEŁ BIELICKI}

Instytut Historii i Stosunków Międzynarodowych

Uniwersytet Kazimierza Wielkiego w Bydgoszczy

ul. Poniatowskiego 12, 85-671 Bydgoszcz

bielicki11@gmail.com

\section{Bibliografia}

\section{Publikacje zwarte}

Berger, L. (1946). Teologowie sowieccy na ziemiach biblijnych. Dziennik Polski i Dziennik Żotnierza, 6.

Bielicki, P. (2016). Instrumenty polityki rosyjskiej w konflikcie syryjskim - część 1, Sensus Historiae, 3, s. 193-211.

Bohdanowicz, L. (1949). Rosja, Polska a świat muzułmański. Kurs Spraw Wschodnich, s. 1-28.

Falkowski, M. (2015). Ramzanistan. Czeczeński problem Rosji, Punkt Widzenia OSW, 53, s. $1-37$.

Felsztiński, J. Litwinienko, A. (2007). Wysadzić Rosję. Poznań: Dom Wydawniczy Rebis.

Legucka, A. (2013). Geopolityczne uwarunkowania i konsekwencje konfliktów zbrojnych na obszarze postradzieckim, Warszawa: Wydawnictwo Difin.

Jaszyn I, (2016). A threat to national security. An independent expert raport, Moscow: Boris Nemtsov Foundation.

Pesnot, P. (2013). Rosyjscy szpiedzy. Od Stalina do Putina. Warszawa: Wydawnictwo MUZA S.A.

Suworow, W. (2014). Alfabet Suworowa. Poznań: Dom Wydawniczy Rebis.

Szabaciuk, A. (2014). Polityka Federacji Rosyjskiej wobec Republiki Czeczeńskiej. Podstawowe uwarunkowania, założenia i próba oceny. Rocznik Instytutu Europy Środkowo-Wschodniej, 1(12).

Zygar, M. (2017). Tajne życie dworu Władimira Putina. Warszawa: Wydawnictwo AGORA S.A.

\section{Netografia}

Aliyev, H. (2017, 11 grudnia), Anti-Kadyrov Chechens are Targeted in Ukraine. Pobrane z: https://www.cacianalyst.org/publications/analytical-articles/item/13487-anti-Kadyrov-chechens-are-targeted-in-ukraine.html.

Domańska, M. Górecki, W. (2017, 6 września), Polityka zagraniczna Rosji - koncesje wobec Kadyrowa. Pobrane z: https://www.osw.waw.pl/pl/publikacje/analizy/2017-09-06/ Kadyrow-zaczyna-dyktowac-warunki-kremlowi.

Dżutsati, V. (2016, 23 lutego), Chechen Oil Takeover May Be The Start Of Russian Power Devolution. Pobrane z: https://oilprice.com/Latest-Energy-News/World-News/Chechen-Oil-Takeover-May-Be-The-Start-Of-Russian-Power-Devolution.html.

Dżutsati, V. (2016, 11 stycznia), Putin Hands Oil and Gas Company to Chechen Authorities. Pobrane z: https://jamestown.org/program/putin-hands-oil-and-gascompany-to-chechen-authorities-2/. 
Falkowski, M. Żochowski, P. (2015, 29 kwietnia), Rosja: konflikt resortów siłowych z Kadyrowem. Pobrane z: https://www.osw.waw.pl/pl/publikacje/analizy/2015-04-29/ rosja-konflikt-resortow-silowych-z-Kadyrowem.

Fuller, L. (2016, 9 stycznia): Prospects for Chechnya's oil sector remain unclear. Pobrane Z: https://www.rferl.org/a/caucasus-report-chechnya-oil-sector-prospects-kadyrov/28221846.html.

Fuller, L. (2017, 4 września), Publicly Out Of Step With Kremlin, Chechnya's Kadyrov Rallies Around Rohingya. Pobrane z: https://www.rferl.org/a/russia-chechnya-kadyrov-rallies-for-rohingya-illustrate-clout/28716244.html.

Górzyński, O. (2017, 4 września), Masowe demonstracje w obronie muzułmanów. Kadyrow występuje przeciwko Putinowi? Pobrane z: https://wiadomosci.wp.pl/masowe-demonstracje-w-obronie-muzulmanow-Kadyrow-wystepuje-przeciwko-putinowi-6162579904943745a.

Górzyński, O. (2016, 26 października), Zamach na ukraińskiego polityka. Zleceniodawca Ramzan Kadyrow. Pobrane z: https://wiadomosci.wp.pl/zamach-na-ukrainskiego-polityka-zleceniodawca-ramzan-Kadyrow-6180977387202177a.

Jacobson, C. (2012, 27 kwietnia), Chechnya: A Difficult Cornerstone in Russian Security. Pobrane z: http://geohistory.today/chechnya/.

Kuczynski, G. (2016, 16 marca), Ramzan vs. Igor, which is the battle for the Chechen oil. Pobrane z: http://genoil.ca/kuczynski-ramzan-vs-igor-which-is-the-battle-for-the -chechen-oil/.

Menabde, G. (2015, 1 grudnia), Islamic State's Influence Increases in Georgia. Pobrane z: http://www.jamestown.org/single/?tx_ttnews[tt_news] $=44847 \&$ no_cache $=1 \#$. VxKlm3pgI4A.

Pukhov, R. (2015, 21 października), The Russian Military Campaign in Syria: The Balance of Forces and Possible Risks. Pobrane z: http://eng.globalaffairs.ru/book/The-Russian-Military-Campaign-in-Syria-The-Balance-of-Forces-and-Possible-Risks-17764.

Soska, M. (2014), Kadyrow - z Czeczenii, przez Ukrainę, na Kreml? Pobrane z: http:// www.mysl-polska.pl/node/114.

Suckhov, M.A. (2016, listopad), What is Chechnya's Kadyrov up to in Middle East?. Pobrane z: http://www.al-monitor.com/pulse/originals/2016/11/chechnya-kadyrov-russia-mideast-diplomacy.html\#ixzz534TuuHPa.

Zając, P. (2016, 27 czerwca), Geopolityczne znaczenie Czeczenii w polityce Federacji Rosyjskiej. Pobrane z: http://geopolityka.net/geopolityczne-znaczenie-czeczenii -w-polityce-federacji-rosyjskiej/.

Ж.-Батист, Ноде. (2014, 22 października), Сирия: новая кровавая сага чечениев. Pobrane z: http://inosmi.ru/world/20141022/223839890.html.

«Bestia Putina, która ma tyleż władzy nad swym panem, co pan nad niq̨". (2016, 2 lutego), Pobrane z: https://www.tvn24.pl/wiadomosci-ze-swiata,2/ramzan-kadyrow-analitycy-o-jego-roli-przy-putinie,615672.html.

Białoruś została sama, nie mamy sojuszników, nie mamy na kogo liczyć”. (2017, 22 września). Pobrane z: https://kresy24.pl/bialorus-zostala-sama-nie-mamy-sojusznikow -nie-mamy-na-kogo-liczyc/.

Gazprom agrees with Bahrain on participation in oil and gas prospecting-Chechen leader. (2017, 6 kwietnia). Pobrane z: http://tass.com/economy/939662. 
Geographic position and natural resources of Chechen Republic. (2003, 21 kwietnia). Pobrane z: http://www.eng.kavkaz-uzel.eu/articles/499/.

Kadyrov predicts Ukraine's accession into 'great Russia'. (2017, 11 grudnia). Pobrane z: https://www.rt.com/politics/412725-Kadyrov-predicts-ukraine-seeking-accession/. Łukaszenka i Kadyrow: „,braterska” wymiana uprzejmości. (2017, 25 września). Pobrane z: http://belsat.eu/pl/news/lukaszenka-i-Kadyrow-wymiana-uprzejmosci/.

Państwo Islamskie a Rosja, czyli o sojuszu niekoniecznie z przypadku. (2015, 12 października). Pobrane z: http://rebelya.pl/post/9062/panstwo-islamskie-a-rosja-czyli -o-sojuszu-nieko.

Risky Russian Moment in Syria. (2015, 1 października). Pobrane z: http://www.cfr.org/ syria/risky-russian-moment-syria/p37087. 